\section{Acute myocarditis after coronavirus disease 2019 vaccination}

To the Editor,

We would like to share our ideas on the article titled, "Acute myocarditis after the second dose of SARS-CoV-2 vaccine: Serendipity or atypical causal relationship?" by Cereda et al. (1), who concluded that "Post-vaccination myocarditis is an infrequent event." The issue of cardiac complications after receiving the coronavirus disease 2019 (COVID-19) vaccine is an important one in cardiology. Sporadic cases with cardiac complications have been reported. Diagnosis is a clinical challenge. In a previous report, it was suggested that a complete evaluation, which includes a cardiac enzyme test (including troponin), electrocardiography, and imaging is required (2). In this study by Cereda et al. (1), all the evidence, except for the cardiac enzyme data, were provided. The difficulty is also owing to the lack of a complete study on the causal relationship. There are many possible interferences. The diagnosis is difficult if the patient has underlying heart disease. In addition, there is usually a lack of cases reported in the literature. The rarity of case reports might also be because of local policies in some settings for no report on COVID-19 vaccine adverse effects (3).

\section{Beuy Joob (D), Viroj Wiwanitkit1 ${ }^{1}$}

Private Academic Consultant Center; Bangkok-Thailand 1Department of Community Medicine, Dr. DY Patil University; Pune-India

\section{References}

1. Cereda A, Conca C, Barbieri L, Ferrante G, Tumminello G, Lucreziotti $\mathrm{S}$, et al. Acute myocarditis after the second dose of SARS-CoV-2 vaccine: Serendipity or atypical causal relationship? Anatol J Cardiol 2021; 25: 522-3. [Crossref]

2. Mansour J, Short RG, Bhalla S, Woodard PK, Verma A, Robinson X, et al. Acute myocarditis after a second dose of the mRNA COVID19 vaccine: a report of two cases. Clin Imaging 2021; 78: 247-9. [Crossref]

3. Mishra S, Mungmunpuntipantip I. Editorial: a good case report that might not be accepted for publication in a journal. Case Study Case Rep 2021; 11: 32-3.

Address for Correspondence: Beuy Joob, MD, Private Academic Consultant Center; Bangkok-Thailand E-mail: beuyjoob@hotmail.com (c) Copyright 2021 by Turkish Society of Cardiology Available online at www.anatoljcardiol.com DOI:10.5152/AnatolJCardiol.2021.689

\section{Author’s Reply}

To the Editor,

First of all, we would like to thank the editorial board of the Anatolian Journal of Cardiology for its open policy toward case reports and clinical images.

Despite their subordination to other studies in the hierarchy of evidence, well-written case reports play an important role in generating evidence and providing valuable information to clinicians. Our case report (1) is one of the first published cases regarding this possible vaccine complication, with all the scientific doubts and merits of "serendipity."

Scientific evidence grows over time, and "serendipity" has now become a "likely association," also supported by case reports.

Although a causal relationship between mRNA vaccines and myocarditis has not yet been established, consultants from the US Center for Disease Control and Prevention have stated that a "likely association" exists.

In the available case series, as in our report (1), patients presented with chest pain, electrocardiogram changes, elevated troponin, and cardiovascular magnetic resonance imaging results, which were typical of myocarditis. The troponin values were elevated in all the individuals and appeared to peak the day after admission. Similar to the other cases, the basal value of high-sensitivity troponin I was 1.4 times higher than the normal range in our patient. The peak troponin and creatine phosphokinase-MB values (on day 5 of admission) were $12.2 \mathrm{ng} / \mathrm{mL}$ and $22 \mathrm{ng} / \mathrm{mL}$, respectively.

The temporal adverb "infrequent' is perhaps inappropriate but presumable with the estimate of the real incidence being verified by international drug regulatory agencies.

The Centers for Disease Control Vaccine Adverse Event Reporting System (last updated in June 2021) reports a rate of approximately 16 cases per million after the administration of the second dose of the mRNA-1273 vaccines (2-4).

The known and potential benefits of COVID-19 vaccination outweigh the known and potential risks, including the possible risk of myocarditis or pericarditis. However, in this pandemic phase, all healthcare providers should be vigilant for myocarditis after COVID-19 mRNA vaccination, and further research is required to understand the long-term cardiovascular risks. The benefits of vaccination are thought to outweigh the risks of an "infrequent" complications.

The case reports and case series are relevant to better understand rare complications (benign and self-limited); however, they must not interrupt the march toward maximal vaccination against SARS-CoV-2, and it should be carried out as expeditiously as possible. 
Alberto Cereda (D), Gabriele Tumminello (D)

Department of Cardiology, ASST Santi Paolo e Carlo; Milan-Italy

\section{References}

1. Cereda A, Conca C, Barbieri L, Ferrante G, Tumminello G, Lucreziotti $\mathrm{S}$, et al. Acute myocarditis after the second dose of SARS-CoV-2 vaccine: Serendipity or atypical causal relationship? Anatol J Cardiol 2021; 25: 522-3. [Crossref]

2. Larson KF, Ammirati E, Adler ED, Cooper LT Jr, Hong KN, Saponara G, et al. Myocarditis After BNT162b2 and mRNA-1273 Vaccination. Circulation 2021; 144: 506-8. [Crossref]

3. Marshall M, Ferguson ID, Lewis $P$, Jaggi P, Gagliardo C, Collins JS, et al. Symptomatic Acute Myocarditis in 7 Adolescents After
Pfizer-BioNTech COVID-19 Vaccination. Pediatrics 2021; 148: e2021052478. [Crossref]

4. Kim HW, Jenista ER, Wendell DC, Azevedo CF, Campbell MJ, Darty $\mathrm{SN}$, et al. Patients With Acute Myocarditis Following mRNA COVID-19 Vaccination. JAMA Cardiol 2021; 6: 1196-201. [Crossref]

Address for Correspondence: Alberto Cereda, MD,

Department of Cardiovascular, ASST Santi Paolo e Carlo; Milan-Italy Phone: +393200883375

E-mail: alberto.cereda@asst-santipaolocarlo.it CCopyright 2021 by Turkish Society of Cardiology Available online at www.anatoljcardiol.com 